\title{
Representations on adherence to the treatment of Multidrug-Resistant Tuberculosis*
}

\author{
Representações sobre a adesão ao tratamento da Tuberculose Multidroga Resistente \\ Representaciones sobre la adhesión al tratamiento de la Tuberculosis Multidroga Resistente
}

Kuitéria Ribeiro Ferreira ${ }^{1}$, Giovanna Mariah Orlandi², Talina Carla da Silva², Maria Rita Bertolozzi ${ }^{2}$, Francisco Oscar de Siqueira França ${ }^{3}$, Amy Bender ${ }^{4}$

How to cite this article:

Ferreira KR, Orlandi GM, Silva TC, Bertolozzi MR, França FOS, Bender A. Representations on adherence to the treatment of Multidrug-Resistant Tuberculosis. Rev Esc Enferm USP. 2018;52:e03412. DOI: http://dx.doi.org/10.1590/S1980-220X2018010303412

\footnotetext{
* Extracted from the thesis: "A adesão ao tratamento no caso da tuberculose multirresistente", Escola de Enfermagem da Universidade de São Paulo, 2014.

1 Universidade Paulista, São

Paulo, São Paulo, Brazil.

${ }^{2}$ Universidade de São Paulo, Escola de Enfermagem, Departamento de Enfermagem em Saúde Coletiva, São Paulo, SP, Brazil.

${ }^{3}$ Universidade de São Paulo, Faculdade de Medicina, Departamento de Moléstias Infecciosas e Parasitárias, São Paulo, SP, Brazil.

${ }^{4}$ University of Toronto, Faculty of Nursing, Toronto, Ontário, Canada.
}

\begin{abstract}
Objective: To identify representations regarding adherence to the treatment of multidrug-resistant tuberculosis from the perspective of patients who were discharged upon being cured. Method: A qualitative study with patients who completed the drug treatment for multidrug-resistant tuberculosis in São Paulo. Social Determination was used to interpret the health-disease process, and the testimonies were analyzed according to dialectical hermeneutics and the discourse analysis technique. Results: Twenty-one patients were interviewed. The majority $(80.9 \%)$ were men, in the productive age group $(90.4 \%)$ and on sick leave or unemployed (57.2\%) during the treatment. Based on the testimonies, three categories associated with adherence to treatment emerged: the desire to live, support for the development of treatment and care provided by the health services. Conclusion: For the study sample, adherence to the treatment of multidrug-resistant tuberculosis was related to having a life project and support from the family and health professionals. Free treatment is fundamental for adherence, given the fragilities arising from the social insertion of people affected by the disease. Therefore, special attention is required from the health services to understand patient needs.
\end{abstract}

\section{DESCRIPTORS}

Tuberculosis; Tuberculosis, Multidrug-Resistant; Medication Adherence; Health Services Accessibility; Public Health Nursing. 


\section{INTRODUCTION}

With the advent of chemotherapy and advances in diagnostics, it was believed that tuberculosis (TB) would be easily controlled. However, it continues to present relevance as a public health problem despite the possibility of being cured through appropriate treatment ${ }^{(1)}$.

It is estimated that in 2016 there were 10.4 million new cases of TB and 490 thousand new cases of MultidrugResistant TB (MDR-TB). In Brazil, there were a thousand new cases of TB and a thousand cases of MDR-TB ${ }^{(2)}$. In addition to the alarming number of MDR-TB cases worldwide, the World Health Organization (WHO) estimates that only $20 \%(125,000)$ of these cases were reported in 2015, and that the treatment success rate was 52\% in 2013. This data is even more surprising for extremely resistant $\mathrm{TB}$, only reaching a success rate in $28 \%$ of patients ${ }^{(3)}$. Of the countries with high MDR-TB occurrence, six countries including Brazil present subnational data on monitoring resistant cases. Just in 2014, Brazil launched a comprehensive national surveillance system to monitor drug resistance ${ }^{(3)}$.

TB is defined as MDR-TB when resistance to at least rifampicin and isoniazid is observed, which together with pyrazinamide and ethambutol constitute the basic regimen for treatment of TB. Isoniazid and rifampicin are the drugs that most present bactericidal activity, and the latter has greater sterilizing power. MDR-TB demands a much longer treatment period, corresponding to six months in the basic regimen being extended to 18 to 24 months, as long as the clinical and radiological evolution are considered, and the bacteriological examination is negative. The complexity of MDR-TB treatment is even greater when considering that the medication is injectable in the first six months, and it can produce very relevant side effects such as nephrotoxicity, hearing loss, peripheral neuropathy, optic neuritis, anaphylaxis, seizures, psychotic symptoms, nausea, vomiting, arthralgia, headache, tinnitus and insomnia ${ }^{(4)}$.

Several studies affirm that attention and constant vigilance for MDR-TB by the health authorities is necessary since it represents a further challenge for controlling $\mathrm{TB}^{(5-6)}$. However, there is a lack of studies on the aspects related to adherence to MDR-TB treatment. Among the studies found, most of them do not explore the association between adherence and the aspects closely related to the causality network, such as the living and working conditions of the patients ${ }^{(7-9)}$.

Based on the assumption that adherence to MDR-TB treatment is associated with these conditions, in addition to access to health services and the way the TB Control Program is operationalized, this study aimed to identify representations about the adherence of people who successfully completed treatment for MDR-TB in a tertiary referral center in the state of São Paulo.

\section{METHOD}

A descriptive study with a qualitative approach was carried out. The individual testimonies constituted the raw material for apprehension and analysis of the conceptions regarding the health-disease process, the living reality of the patient being treated, the health care and adherence to treatment.
The study was conducted at a Tertiary Reference Center for TB and MDR-TB control, located in the central region of the city of São Paulo, administered by the state government. We interviewed people who experienced treatment for pulmonary MDR-TB and who were in follow-up after being cured, from April to September 2012. We chose to interview patients who were discharged from 2008 to 2012, considering the most recent discharge period to ensure greater probability of attending the consultations, considering that these patients still had follow-up consultations. Exclusion criteria were: being less than 18 years old and having a mental disorder that made it impossible to participate in the study.

A questionnaire containing open questions was used in order to enable the subjects to report their experiences of the disease, their treatment, adherence, as well as the difficulties and facilities found for correct conduction of the treatment until being cured. In addition to the interviews, a field diary was used with the aim of promoting hermeneutic reading. The testimonies were recorded and transcribed in full. The adapted and appropriate technique of discourse analysis based on the Theory of the Generation of Sense was used, which enables analyzing thematic phrases ${ }^{(10-11)}$. Each subject received a letter of identification, followed by a number referring to the corresponding thematic phrase (example: B26 corresponds to the 26 thematic phrase of subject $B$ ). These thematic phrases were subsequently grouped and constituted the following sets of themes: the healthdisease process in MDR-TB and adherence to treatment.

The understanding that TB is socially determined was used for analysis of the study object. Such a conception places health and disease as moments of the same process, determined by the way each individual is inserted in the production and social reproduction modes ${ }^{(12)}$. Therefore, the healthdisease process is understood through the structural processes that govern society and which allow explaining the living conditions of the people and the social reproduction profiles of the different groups, from which the potentialities and/or attrition processes that influence health and disease occur ${ }^{(13)}$.

This project was approved by the Ethics Committee (process no. 996/2011) and all respondents participated by signing the clear and Informed Consent Form (ICF).

\section{RESULTS}

Twenty-one people were interviewed, 17 (80.9\%) men and 4 (9.1\%) women who adhered to the MDR-TB treatment. The majority was in the age group between 18 and 55 years $(19 ; 90.4 \%)$, had 9 or more years of education (11; $52.4 \%)$, lived with a partner $(12 ; 57.1 \%)$ and had a fixed residence in the city of São Paulo (10, 47.5\%). The characteristics related to working and living conditions and to the health-disease process at the time of MDR-TB treatment are shown in Table 1 . We can point out that $12(57.2 \%)$ patients were unemployed or on sick leave, 18 (85.7\%) stated that their income was sufficient for food, all were residing in brick housing, with apparently adequate housing conditions. It is very relevant that $3(14.3 \%)$ people had previously had the treatment three times and that almost one third was alcohol and tobacco users. 
Table 1 - Distribution of study subjects according to characteristics related to working conditions, life conditions and health-disease process during the treatment of multidrug-resistant tuberculosis São Paulo, SP, Brazil, 2012.

\begin{tabular}{|c|c|c|}
\hline Characteristics of working conditions & $\mathbf{N}$ & $\%$ \\
\hline \multicolumn{3}{|l|}{ Work status: } \\
\hline Employed & 9 & 42.8 \\
\hline On sick leave & 6 & 28.6 \\
\hline Unemployed & 6 & 28.6 \\
\hline Characteristics of living conditions & $\mathbf{N}$ & $\%$ \\
\hline \multicolumn{3}{|l|}{ The income is enough for: } \\
\hline Housing & 12 & 57.1 \\
\hline Food & 18 & 85.7 \\
\hline Transportation & 11 & 52.4 \\
\hline Leisure & 12 & 57.1 \\
\hline Clothing & 10 & 47.6 \\
\hline \multicolumn{3}{|l|}{ Housing characteristics: } \\
\hline Brick & 21 & 100.0 \\
\hline Four or more rooms & 14 & 66.7 \\
\hline Adequate ventilation and lighting & 15 & 71.4 \\
\hline Characteristics of the health-disease process & $\mathbf{N}$ & $\%$ \\
\hline \multicolumn{3}{|l|}{ Previous treatment of the disease: } \\
\hline One & 8 & 38.1 \\
\hline Two & 7 & 33.3 \\
\hline Three & 3 & 14.3 \\
\hline \multicolumn{3}{|l|}{ Consumption: } \\
\hline Alcohol & 2 & 9.5 \\
\hline Tobacco & 2 & 9.5 \\
\hline Alcohol and tobacco & 6 & 28.6 \\
\hline
\end{tabular}

Analysis of the testimonies showed that adherence to MDR-TB treatment is a huge struggle (E41; G18; M12,149), where you need to be really strong (B26, M72, 87, 121, 169). On this theme, three categories emerged: the desire to live, support for the development of treatment and the organization of health services (Figure 1). Each analytical category is supported by constitutive elements, as shown in Chart 1 .

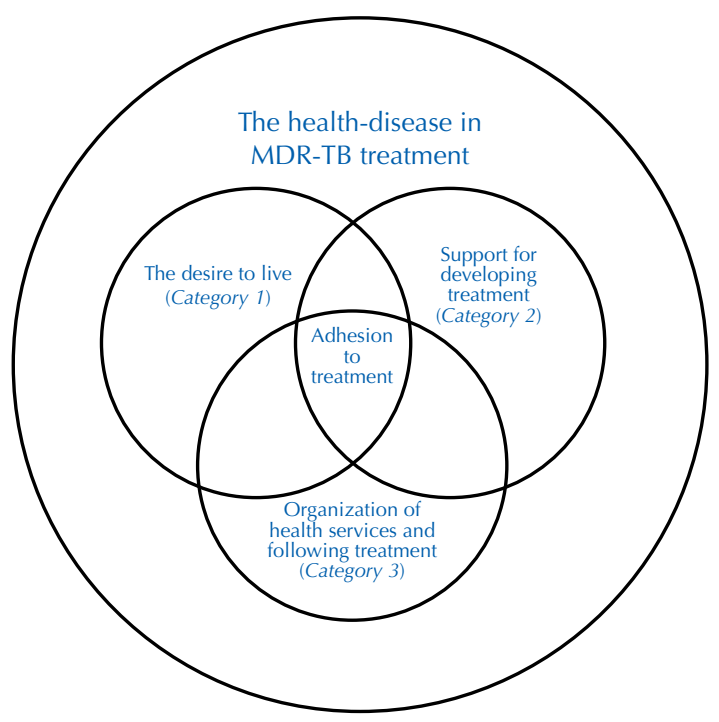

Figure 1 - Adherence to the treatment of multidrug-resistant tuberculosis.
Chart 1 - Categories of analysis and their constituent elements São Paulo, SP, Brazil, 2012.

\begin{tabular}{|c|c|c|}
\hline $\begin{array}{l}\text { Desire } \\
\text { to live }\end{array}$ & $\begin{array}{c}\text { Support for } \\
\text { developing treatment }\end{array}$ & $\begin{array}{l}\text { Assistance from } \\
\text { the health services }\end{array}$ \\
\hline $\begin{array}{l}\text { - Treatment } \\
\text { and life } \\
\text { - MDR-TB } \\
\text { and death }\end{array}$ & $\begin{array}{l}\text { - Physical } \\
\text { - Emotional } \\
\text { - Financial }\end{array}$ & $\begin{array}{l}\text { - Directly Observed Therapy } \\
\text { - Medical consultations in the } \\
\text { reference center } \\
\text { - Free health care }\end{array}$ \\
\hline
\end{tabular}

\section{Desire to LIVE}

According to the subjects, the desire to live is essential for adherence to treatment, because it allows to face the obstacles imposed by the disease. The testimonies pointed out that MDR-TB treatment is associated with life and that achieving health is considered as the first need and human value. The desire to fight against the disease is allied to the concern with the family, since the people affected by the illness feel like they are the providers and are responsible for maintaining the household.

MDR-TB is related to death, which paradoxically has repercussions on the desire to live and induces patients to adhere to treatment. The disease is considered by the interviewees as severe (M175), for presenting more severe and intense signs and symptoms than the non-resistant form of pulmonary TB. Some signs and symptoms and conditions, reported as more severe were: bloody sputum, becoming bedridden, inability to develop simple everyday activities (bathing and walking), and dyspnea, which are associated with the sensation of being basically dead (C23; E30; J18; L1, 16; S21, 24; R20; P49, 67).

\section{SUPPORT FOR THE DEVELOPMENT OF TREATMENT}

The debilitation caused by the disease is brought about by the generalized feeling of weakness, evidenced by mention of the incapacity for the most basic everyday life activities (bathing and eating), and by the dependence of other people for accomplishing household activities and the incapacity to take care of children.

On the other hand, family support during treatment and medical consultations was pointed out as very important for adherence to treatment, mainly due to the physical weakness of the subjects, which also limits their commute to the health service. In addition, preparation of the patient's food was pointed out as fundamental, which ensured more regular and better meals.

The testimonies showed that the strength (J28) and words of comfort and affection $(\mathrm{C} 28,29,44 ; \mathrm{D} 21,35 ; \mathrm{E} 26,28$; F17, 18; G21; H17, 26; J19, 28; L6; O38, 39, 50, 71, 75; P72, 73; Q24, 25; R29; T31-33; U28) offered by family and friends during the disease treatment related to emotional support. The feeling of being loved by family members, friends, and health professionals was mentioned as being relevant for adherence to treatment. The bond with the health professional was characterized by user embracement, care, listening, attention, clarification of doubts, being called by their name, among others. This form of care evidences the health professional's desire to help the subject overcome the disease.

The disease excludes the person from the labor market, which triggers serious socioeconomic problems. The 
weaknesses caused by not earning their monthly income on the subject and his/her family makes the material/financial support (offered by the government, non-governmental institutions, health professionals and family members) essential for maintaining their life and adherence to treatment. Regarding this support, among the aids offered by the Tuberculosis Control Program we can point out the importance of the transportation voucher for monthly attendance to medical consultations. The basic food package (cesta básica) and the financial support offered by the Bolsa Familia (Family Grant) Programme were identified as enhancers of adherence to treatment, but also contribute to feeding dependent children.

\section{AsSISTANCE FROM THE HEALTH SERVICES}

The representations that emerged from the testimonies reveal that Directly Observed Therapy (DOT) is a strategy that supports adherence to MDR-TB treatment and enables detection and monitoring of adverse reactions to medication. The need to sign the DOT follow-up form is understood by the patient as a requirement for the health care continuity, so that the subject believes that this instrument guarantees care continuity in the health unit.

On the other hand, the need to attend medical appointments at the referral center is not perceived as beneficial, given the weaknesses caused by the long commute from home, the physical weakness to move, the inadequate conditions of public transportation, the long waiting times for care, among other reasons. However, the quality of the care provided by the doctors and nurses of the service was emphasized, which contributed to treatment follow-up.

The medication provision by the public service is also considered as fundamental for the correct treatment follow-up:

The drugs are expensive (...), if we had to buy them, (...) I would bave died because I cannot afford it (A26; E45).

On the other hand, irregularity in the medication supply was mentioned, which made it difficult to perform the correct treatment (B30), although this fact did not interfere in the evolution to being cured.

The following were reported among the main obstacles to adherence: injectable medication, high number of pills, the long treatment time, daily visits to the health unit for accomplishing the DOT, and the attendance to the monthly consultations at the reference center.

\section{DISCUSSION}

The present study identified that the desire to live, support for developing the treatment and aspects related to health care, and the TB Control Program are elements that measure adherence to MDR-TB treatment. The findings show that adherence to MDR-TB treatment involves aspects which go beyond the singular and volitional dimension of the individual and refer to the way the Control Program operates, as well as the organization of health services.

The interviewed subjects showed that treatment adherence is strongly linked to the desire to be cured in the face of the inevitability of death. In addition to the life project, the personal motivation for treatment also stems from improvement in the symptomatology, which gives greater hope of being cured and to overcoming barriers, corroborating other studies on this theme $e^{(9,14)}$.

Physical and mental suffering was evidenced as a consequence of the disease, which negatively affects the lives of patients who need to leave work and causes financial difficulties, which has also been identified in other studies ${ }^{(15-16)}$. In addition, the importance of family support is highlighted, especially when there is a shared home, which makes the health-disease process more humanized ${ }^{(16-18)}$.

As this is a disease that is consecrated to social conditions, there is a need for government protection through social protection policies, so that affected people can minimize economic barriers imposed by illness and not abandon treatment. Regarding these measures, studies show that measures that alleviate suffering and financial burden such as social incentives, especially support for food and transportation, can positively contribute to patients' adherence to MDR-TB treatment, mainly due to the debilitating nature of the disease, the long-term care and loss of income, which may put these patients at special risk due to catastrophic costs $^{(19-21)}$. Despite these incentives such as the provision of basic food packages and transportation vouchers, these are palliative measures that are not capable of changing people's living conditions, although they do contribute to coping with the disease ${ }^{(22)}$.

The means by which health care is organized in care services and patient care consisted of an important result that emerged from the patients' testimonials. In the study municipality, MDR-TB treatment is performed through "cooperative supervision" between the reference center and the health unit. This form of treatment being decentralized to better follow the patient's treatment has also been observed in other countries, such as in South Africa and Peru, which perform the care in clinics close to patients' homes or through home visits rather than hospitalizing them throughout the treatment; a common practice in these countries and which has not been totally abolished in South Africa. These countries follow the Guidelines for Programmatic Management of Drug Resistant Tuberculosis formulated by WHO, which propose health education actions for the patient and family members, in addition to treatment ${ }^{(23-24)}$.

The DOT is recommended by the Ministry of Health in Brazil, as well as by the WHO. It is not new that this treatment modality assists in treatment adherence and curing the disease. However, DOT becomes even more important for MDR-TB treatment due to the frequent adverse reactions and the long treatment period, which are the main reasons for treatment being discontinued ${ }^{(25)}$. In addition, establishing a bond and trust, both of which are important for treatment adherence, are derived from daily contact, user embracement, and from qualified listening, which allows the professional to identify the needs of the person being treated for MDR-TB, in addition to sharing problems that afflict the patient, thereby enabling to strengthen the patient for the treatment ${ }^{(7,26)}$. 
This study evidenced the shortcomings encountered by individuals with MDR-TB and who, even in adverse situations, were transposed, which resulted in them being cured. In addition, it has contributed to fill some knowledge gaps, as there is a lack of evidence on the obstacles faced by people with MDR-TB and on overcoming them ${ }^{(16)}$.

\section{CONCLUSION}

The present investigation indicates several issues involved in adherence to MDR-TB treatment. Above all, the representations about the health-disease process focus on the desire to live, support for developing the treatment in all its dimensions (physical, emotional/psychological and financial) and how health services should offer the care and be organized to conduct the disease treatment. Although following the treatment in the health unit is a painful process, the DOT enables forming a bond and confidence to overcome the disease. In addition, the importance of the treatment being free was verified given the peculiar social insertion of the people affected by the illness.

This study has also shown that there is a need to establish policies that improve living and working conditions which are a collective necessity, and as such should be the responsibility of the State.

\section{RESUMO}

Objetivo: Identificar representações a respeito da adesão ao tratamento da tuberculose multidroga resistente na perspectiva de pacientes que obtiveram alta por cura. Método: Estudo qualitativo com pacientes que completaram o tratamento medicamentoso da tuberculose multidroga resistente em São Paulo. Utilizou-se da Determinação Social para interpretar o processo saúde-doença, e os depoimentos foram analisados segundo a hermenêutica-dialética e a técnica de análise de discurso. Resultados: Entrevistaram-se 21 pacientes. A maioria $(80,9 \%)$ era homens, na faixa etária produtiva $(90,4 \%)$ e afastada do trabalho ou desempregada $(57,2 \%)$ durante o tratamento. Dos depoimentos, emergiram três categorias associadas à adesão ao tratamento: o desejo de viver, o suporte para o desenvolvimento do tratamento e a assistência nos serviços de saúde. Conclusão: Para a amostra do estudo, a adesão ao tratamento da tuberculose multidroga resistente esteve relacionada a ter um projeto de vida e ao apoio familiar e dos profissionais de saúde. A gratuidade do tratamento é fundamental para a adesão, dadas as fragilidades decorrentes da inserção social das pessoas acometidas pela doença. Requer-se, portanto, particular atenção dos serviços de saúde para compreender as necessidades dos doentes.

\section{DESCRITORES}

Tuberculose; Tuberculose Resistente a Múltiplos Medicamentos; Adesão à Medicação; Acesso aos Serviços de Saúde; Enfermagem em Saúde Pública.

\section{RESUMEN}

Objetivo: Identificar representaciones respecto de la adhesión al tratamiento de la tuberculosis multidroga resistente en la perspectiva de pacientes que obtuvieron alta por curación. Método: Estudio cualitativo con pacientes que completaron el tratamiento medicamentoso de la tuberculosis multidroga resistente en São Paulo. Se utilizó la Determinación Social para interpretar el proceso salud-enfermedad, y las declaraciones fueron analizadas según la hermenéutica dialéctica y la técnica de análisis de discurso. Resultados: Se entrevistaron 21 pacientes. La mayoría $(80,9 \%)$ era hombres, en el rango de edad productiva $(90,4 \%)$ y alejados del trabajo o desempleados (57,2\%) durante el tratamiento. De las declaraciones emergieron tres categorías asociadas con la adhesión al tratamiento: el deseo de vivir, el soporte para el desarrollo del tratamiento y la asistencia en los servicios sanitarios. Conclusión: Para la muestra del estudio, la adhesión al tratamiento de la tuberculosis multidroga resistente estuvo relacionada con tener un proyecto de vida y con el apoyo familiar y los profesionales sanitarios. La gratuidad del tratamiento es fundamental para la adhesión, dadas las fragilidades consecuentes de la inserción social de las personas afectadas por la enfermedad. Se requiere, por lo tanto, particular atención de los servicios sanitarios a fin de comprender las necesidades de los enfermos.

\section{DESCRIPTORES}

Tuberculosis; Tuberculosis Resistente a Múltiples Medicamentos; Cumplimiento de la Medicación; Accesibilidad a los Servicios de Salud; Enfermería de Salud Púbica.

\section{REFERENCES}

1. Monedero I, Bhavaraju R, Mendoza-Ticona A, Sánchez-Montalvá A. The paradigm shift to end tuberculosis. Are we ready to assume the changes? Expert Rev Respir Med. 2017;11(7):565-79. DOI: https://doi.org/10.1080/17476348.2017.1335599

2. World Health Organization. Global Tuberculosis Report, 2017. Geneva: WHO; 2017.

3. World Health Organization. Global Tuberculosis: WHO Report. Geneva: WHO; 2015.

4. Brasil. Ministério da Saúde; Secretaria de Vigilância em Saúde, Departamento de Vigilância Epidemiológica. Manual de recomendações para o controle da tuberculose no Brasil. Brasília: MS; 2011.

5. Keshavjee S, Farmer PE. Time to put boots on the ground: make universal access to MDR-TB treatment a reality. Int J Tuberc Lung Dis. 2010;14(10):1222-5.

6. Mulisa G, Workneh T, Hordofa N, Suaudi M, Abebe G, Jarso G. Multidrug-resistant Mycobacterium tuberculosis and associated risk factors in Oromia Region of Ethiopia. Int J Infect Dis. 2015;39:57-61. DOI: https://doi.org/10.1016/j.ijid.2015.08.013

7. Queiroz EM, Bertolozzi MR. Tuberculosis: supervised treatment in North, West and East Health Departments of São Paulo. Rev Esc Enferm USP. 2010;44(2):453-61. DOI: http://dx.doi.org/10.1590/S0080-62342010000200030

8. Deshmukh RD, Dhande DJ, Sachdeva KS, Sreenivas A, Kumar AMV, Satyanarayana S, et al. Patient and provider reported reasons for lost to follow up in MDRTB treatment: a qualitative study from a drug resistant TB Centre in India. PLoS One. 2015;10(8):e0135802. DOI: https://doi.org/10.1371/journal.pone.0135802 
9. Horter S, Stringer B, Greig J, Amangeldiev A, Tillashaikhov MN, Parpieva N, et al. Where there is hope: a qualitative study examining patients' adherence to multidrug resistant tuberculosis treatment in Karakalpakstan, Uzbekistan. BCM Infect Dis. 2016;16:362). DOI: https://doi.org/10.1186/s12879-016-1723-8

10. Fiorin JL. Elementos de análise de discurso. São Paulo: EDUSP; 1989.

11. Terra MF, Bertolozzi MR. Does directly observed treatment ("DOTS") contribute to tuberculosis treatment compliance? Rev Lat Am Enfermagem. 2008;16(4):659-64. DOI: http://dx.doi.org/10.1590/S0104-11692008000400002

12. Hino P, Bertolozzi MR, Takahashi RF, Egry EY. Health needs according to the perception of people with pulmonary tuberculosis. Rev Esc Enferm USP. 2012;46(6):1438-45. DOI: http://dx.doi.org/10.1590/S0080-62342012000600022

13. Breilh J. La determinación social de la salud como herramienta de transformación haca una nueva salud pública (salud colectiva). Rev Fac Nac Salud Pública [Internet]. 2013 [citado 2017 fev. 24]; 31 Supl. 1:S13-27. Disponible en: http://www.scielo.org.co/pdf/rfnsp/v31s1/ v31s1a02.pdf

14. Farias SNP, Medeiros CRS, Mauro MYC, Ghelman LG, Araujo EFS. A qualidade de vida de clientes portadores de tuberculose no contexto da Atenção Básica. Rev Enferm UER] [Internet]. 2013 [citado 2017 fev. 24];21(3):349-54. Disponível em: http://www.facenf.uerj.br/v21n3/ v21n3a12.pdf

15. Morris MD, Q uezeda L, Bhat P, Moser K, Smith J, Perez H, et al. Social economic, and psychological impacts of MDR-TB treatment in Tijuana, Mexico: a patient's perspective. Int J Tuberc Lung Dis. 2013;17(7):954-60. DOI: https://doi.org/10.5588/ijtld.12.0480

16. Baral SC, Aryal Y, Bhattrai R, King R, Newel JM. The importance of providing counseling and financial support to patient receiving treatment for multi-drug resistant TB: mixed method qualitative and pilot intervention studies. BMC Public Health. 2014;14:46. DOI: https://doi. org/10.1186/1471-2458-14-46

17. Horter S, Stringer B, Reynolds L, Shoaib M, Kasozi S, Casas EC, et al. "Home is where the patient is": a qualitative analysis of a patientcentred model of care for multi-drug resistant tuberculosis. BMC Health Serv Res. 2014;14:81-8. DOI: https://doi.org/10.1186/14726963-14-81

18. Hoa NB, Nhung NV, Khanh PH, Hai NV, Quyen BTT. Adverse events in the treatment of MDR-TB patients within and outside the NTP in Pham Ngoc Thach hospital, Ho Chi Minh City, Vietnam. BMC Res Notes. 2015;8:809. DOI: https://doi.org/10.1186/s13104-015-1806-4

19. Torrens AW, Rosella D, Boccia D, Maciel EL, Nery JS, Olson ZD et al. Effectiveness of a conditional cash transfer programme on TB cure rate: a retrospective cohort study in Brazil. Trans R Soc Trop Med Hyg. 2016;110(3):199-206. DOI: https://doi.org/10.1093/trstmh/trw011

20. Van Den Hof S, Collins D, Hafidz F, Beyene D, Tursynbayeva A, Tiemersma E. The socioeconomic impact of multidrug resistant tuberculosis on patients: results from Ethiopia, Indonesia and Kazakhstan. BMC Infec Dis. 2016;16:470. DOI: https://doi.org/10.1186/s12879-016$1802-x$

21. Tanimura T, Jaramilo E, Weil D, Raviglione M, Lönnroth K. Financial burden for tuberculosis patients in low-and-middle-income countries: a systematic review. Eur Respir J. 2014;43:1763-75. DOI: https://doi.org/10.1183/09031936.00193413

22. Sousa LO, Mitano F, Lima MCRAA, Sicsú AN, Silva LMC, Palha PF. Short-course therapy for tuberculosis: a discourse analysis. Rev Bras Enferm. 2016;69(6):1089-98. DOI: http://dx.doi.org/10.1590/0034-7167-2016-0330

23. Smart T. Decentralized, patient-centred models of delivering treatment and palliative care for people with M/XDR-TB. HATiP [Internet]. 2010 [cited 2017 Feb 24];166:2-10. Available from: http://www.aidsmap.com/Decentralised-patient-centred-models-of-deliveringtreatment-and-palliative-care-for-people-with-MXDR-TB/page/1520451/

24. Brust JM, Shah NS, Scott M, Chaiyachati K, Lygizos M, Van der Merwe TL, et al. Integrated, home-based treatment for MDR-TB and HIV in rural South Africa: an alternative model of care. Int J Tuberc Lung Dis. 2012;16(8):998-1004. DOI: https://doi.org/10.5588/ijtld.11.0713

25. Park SK, Lee WC, Lee DH, Mitnick CD, Han L, Seung KJ. Self-administered, standardized regimens for multidrug-resistant tuberculosis in South Korea. Int J Tuberc Lung Dis. 2004;8(3):361-8. DOI: https://doi.org/10.5588/ijtld.11.0713

26. Burtscher D, Van den Bergh R, Toktosunov U, Angmo N, Samieva N, Rocillo Arechaga EP "My Favourite Day Is Sunday": Community Perceptions of (Drug-Resistant) Tuberculosis and Ambulatory Tuberculosis Care in Kara Suu District, Osh Province, Kyrgyzstan. PLoS One. 2016;11(3):e0152283. DOI: https://doi.org/10.1371/journal.pone.0152283 